\title{
ISOLATION OF A NEW ANTIBIOTIC SUBSTANCE, AUREOTHRICIN FROM A STRAIN OF STREPOMYCES
}

\author{
By Hamao UMEZAWA, Kenji MaEDA, Hiroko KoSAKA \\ National Institute of Health of Japan, Tokyo
}

Antibiotic strains of streptomyces can be classified according to their antibacterial spectra around their colonies growing on the nutrient agar, as described in the previous paper ${ }^{1)}$, and it can be easily estimated what kinds of antibiotic substances are produced by them. The strains, isolated by us and inhibiting the growth of $\mathrm{E}$. coli, were classified to streptomycin-producing group, streptothricin-group-substances-producing group, geisein-producing group, chloromycetin-producing group, and the fourth group which chiefly produces streptothricin-group-substances. But during further studies we found a strain showing a new antibacterial spectrum and a yellow crystalline antibiotic substance was extracted. It inhibits both the growth of gram positive and that of gram negative bacteria.

Among antibiotic substances obtained from streptomyces, aureomycin ${ }^{2)}$ and xanthomycin $^{3)}$ which were recently found are reported to be yellow colored. Though we do not know the details of these substances, they seem to be different from the substance in this paper. Beșides we can not find the species in literature which is identical with the strain No. 26A producing the antibiotic substance described in this paper, though it seems to be most resembling to Actinomyces farcinicus or Streptomyces lipanii. So we decided to call the antibiotic substance Aureothricin.

\section{Characters of the strain No. 26A.}

It was isolated from the soil at Mitaka, Tokyo, June 1947. And until the beginning of this work (September 1948) it had been successively transfered to dextrose asparagine agar.

On the synthetic medium it shows restricted, wrinkled and light brownish yellow growth which develops deep into the medium. Reverse is brownish and aerial mycelium is white powdery all over the surface of the growth. Brownish yellow solubie pigment is slightly formed. Optimum temperature for the growth lies about at $30^{\circ} \mathrm{C}$. Filaments are blanched. Spirals and conidia can not be visible. On gelatin the colonies are cream coloured without aerial mycelium and the gelatin is very slowly liquefied in the napiform. On the blood agar the growth is restricted greenish gray and developing deep into the medium. Aerial mycelium is grayish white. No soluble pigment and no hemolysis. No liquefaction of blood serum. In the litmus milk, the growth is thick yellowish on the surface, and the aerial mycelium is white on the surface of the growth. Coagulation starts in two or three days and peptonisation starts later and very sowly.

On the potato the growth is yellowish, elevated, and wrinkled, and turns to white, when aerial mycelium is formed. The aerial mycelium is white with greenish tinge 
color of the plug is unchanged or becomes dark. Starch is not hydrolyzed, Nitrites are not produced from nitrates. No tyrosinase.

Though the details of this strain will be written in the other paper by Okami, this strain is resembling to A. farcinicus or S. lipmanii. But it is different from the former in the point of gelatin liquefaction and the change of the milk, and from the latter in the point of not forming nitrites and not hydrolyzing starch.

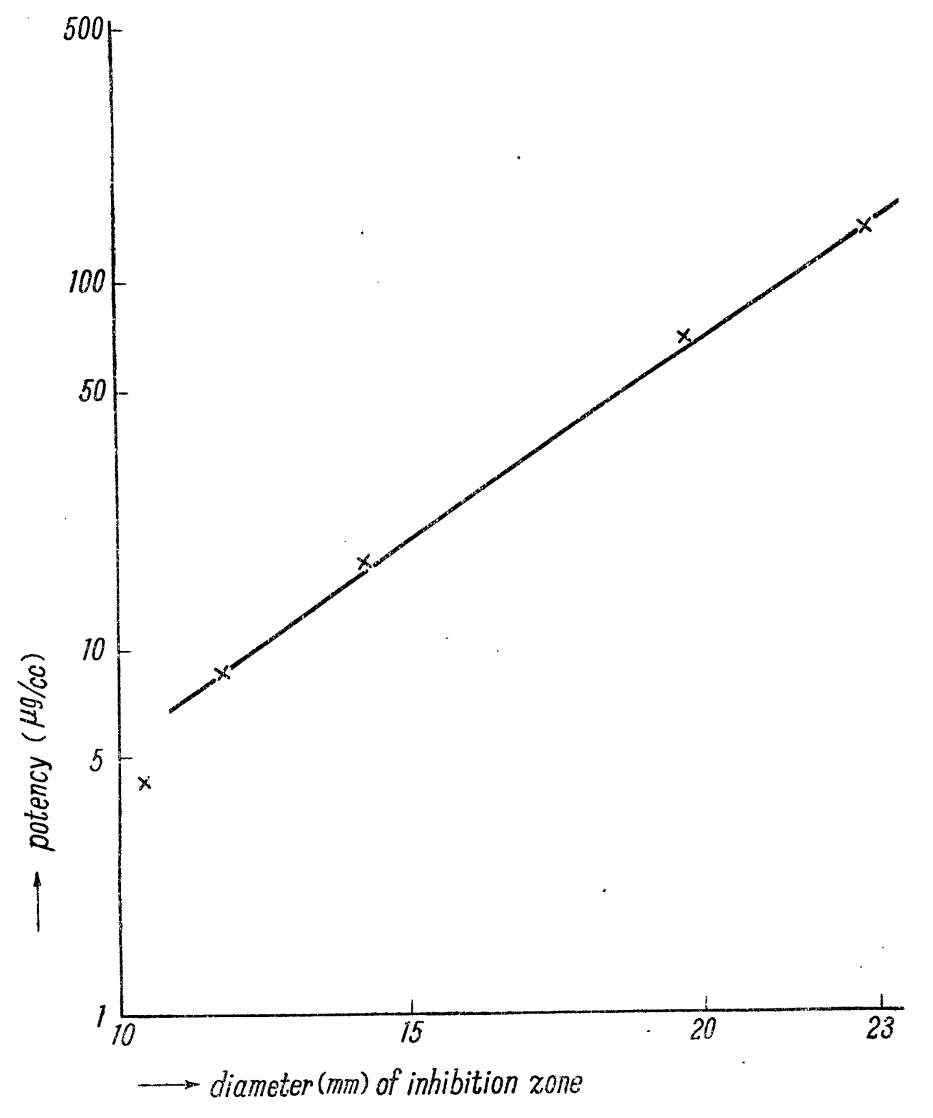

Fig. 1

Relation of diameter (a) of inhibition zone and potency (p)

II. Production of the antibiotic substance in the broth

Fifty $\mathrm{cc}$ of the broth were put in flasks of $350 \mathrm{cc}$ volume and shaken on the shaking machine going and returning in 120 times per minute between $6 \mathrm{~cm}$ amplitude at $25-30^{\circ} \mathrm{C}$.

The potency was measured by cup method, which was performed in the same manner as in the case of penicillin, except instead of S. aureus 209-p E. coli was seeded. As shown Fig. 1, between diameters (d) of inhibition zones and the potencies ( $p$ ) of solutions in the cups there existed the relation, $d=\alpha+\beta \log \mathrm{p}$, where $\alpha$ and $\beta$ 
are constants. The potency was shown in micrograms of the antibiotic crystals in $1 \mathrm{cc}$ of the broth. Among nitrogen sources tested, beef extract rather inhibted the production of the antibiotic substance (Exp. 1 and 2. in Table 1), and the latter was well produced with peptone and corn steep liquor. As shown in Table 1, corn steep liquor seemed to be superior to peptone. Hitherto with anorganic nitrogen sources such as ammonium

Table 1. Comparison of the nitrogen sources, beef extract, peptone and corn steep liquor.

\begin{tabular}{|c|c|c|c|c|c|c|c|c|c|}
\hline \multirow{3}{*}{ Exp. No. } & \multirow{3}{*}{$\begin{array}{c}\text { Beef } \\
\text { extract } \\
\text { added } \\
\text { to } \\
\%\end{array}$} & \multirow{3}{*}{$\begin{array}{l}\text { peptone } \\
\text { added } \\
\text { to } \\
\%\end{array}$} & \multirow{3}{*}{$\begin{array}{c}\text { corn } \\
\text { steep } \\
\text { liquor } \\
\text { added } \\
\text { to } \\
\%\end{array}$} & \multicolumn{6}{|c|}{ potency and $\mathrm{pH}$ of the broth } \\
\hline & & & & \multicolumn{2}{|c|}{2 days } & \multicolumn{2}{|c|}{3 days } & \multicolumn{2}{|c|}{4 days } \\
\hline & & & & $\mu \mathrm{g} / \mathrm{cc}$ & $\mathrm{pH}$ & $\mu \mathrm{g} / \mathrm{cc}$ & $\mathrm{pH}$ & $\mu \mathrm{g} / \mathrm{cc}$ & $\mathrm{pH}$ \\
\hline \multirow{3}{*}{1} & 1 & - & - & 11 & 6.2 & 15 & 6.4 & 12 & 6.0 \\
\hline & 0.5 & 0.5 & - & 30 & 6.0 & 32 & 6.0 & 24 & 6.0 \\
\hline & . - & 1 & - & 39 & 5.8 & 47 & 5.7 & 40 & 5.6 \\
\hline \multirow{7}{*}{2} & - & 1 & - & - & - & 56 & 5.4 & 72 & 6.8 \\
\hline & - & 2 & - & - & - & 64 & 6.0 & 76 & 6.0 \\
\hline & - & 4 & - & - & - & 37 & 5.8 & 54 & 6.6 \\
\hline & - & - & 2 & - & - & 88 & 5.2 & 50 & 6.2 \\
\hline & - & - & 3 & - & - & 80 & 6.0 & 56 & 6.6 \\
\hline & - & - & 4 & - & - & 70 & 6.0 & 64 & 6.0 \\
\hline & - & - & 6 & - & - & 95 & 6.0 & 50 & 7.0 \\
\hline
\end{tabular}

Basal medium: in Exp. 1, 1\% glycerol and $0.5 \% \mathrm{NaCl}$ at $\mathrm{pH} 7.0$, and in Exp. 2, 2\% glycerol and $0.5 \% \mathrm{NaCl}$ at $\mathrm{pH} 7.0$.

Table 2. Comparison of the carbon sources, glycerol, glucose, maltose, dextrine and starch

\begin{tabular}{|c|c|c|c|c|c|c|}
\hline \multirow{3}{*}{ Exp. No. } & \multirow{3}{*}{\multicolumn{2}{|c|}{$\begin{array}{l}\text { Carbon sources } \\
\text { and their concen- } \\
\text { tration added }\end{array}$}} & \multicolumn{4}{|c|}{ Potency and $\mathrm{pH}$ of the broth } \\
\hline & & & \multicolumn{2}{|c|}{3 days } & \multicolumn{2}{|c|}{4 days } \\
\hline & & & $\mu \mathrm{g} / \mathrm{cc}$ & $\mathrm{pH}$ & $\mu \mathrm{g} / 33$ & $\mathrm{pH}$ \\
\hline \multirow{9}{*}{1} & Glycerol & $2 \%$ & 80 & 6.0 & 56 & 6.6 \\
\hline & " & 3 & 95 & 5.6 & 58 & 6.0 \\
\hline & " & 4 & 105 & 5.6 & 56 & 5.8 \\
\hline & Glucose & 2 & 40 & 6.0 & 36 & 6.4 \\
\hline & " & 4 & 56 & 6.0 & 50 & 6.6 \\
\hline & Dextrin & 2 & 50 & 7.0 & 36 & 8.0 \\
\hline & " & 4 & 46 & 7.1 & 36 & 8.0 \\
\hline & Starch & 2 & 35 & 7.0 & 38 & 8.0 \\
\hline & $"$ & 4 & 50 & 6.8 & 72 & 8.0 \\
\hline \multirow{4}{*}{2} & Glycerol & 3 & 88 & 5.8 & 38 & 6.0 \\
\hline & Maltose & 1 & 58 & 7.0 & 21 & 8.0 \\
\hline & $\prime \prime$ & 2 & 70 & 7.0 & 24 & 8.0 \\
\hline & $"$ & 3 & 80 & 6.8 & 21 & 8.4 \\
\hline
\end{tabular}

Basal medium: $3 \%$ corn steep liquor and $0.5 \% \mathrm{NaCl}$. 
Table 3. The effect of sodium chloride, potassium chloride, potassium phosphate, magnesium sulfate and ferrous sulfate on the production of the antibiotic substance.

\begin{tabular}{|c|c|c|c|c|c|c|c|c|}
\hline \multirow{3}{*}{ Added to } & \multicolumn{8}{|c|}{ Potency and $\mathrm{pH}$ of the broth } \\
\hline & \multicolumn{2}{|c|}{1 day } & \multicolumn{2}{|c|}{2 days } & \multicolumn{2}{|c|}{3 days } & \multicolumn{2}{|c|}{4 days } \\
\hline & $\mu \mathrm{g} / \mathrm{cc}$ & $\dot{\mathrm{pH}}$ & $\mu \mathrm{g} / \mathrm{cc}$ & $\mathrm{pH}$ & $\mu \mathrm{g} / \mathrm{cc}$ & $\mathrm{pH}$ & $\mu \mathrm{g} / \mathrm{cc}$ & $\mathrm{pH}$ \\
\hline $0.5 \% \mathrm{NaCl}$ & 12 & 6.2 & 15 & 6.2 & 88 & 5.8 & 38 & 6.0 \\
\hline $1.0 \% \mathrm{NaCl}$ & 13 & 6.6 & 12 & 6.6 & 95 & 5.8 & 38 & 6.0 \\
\hline $0.5 \% \mathrm{NaCl}, 0.5 \% \mathrm{KCl}$ & 13 & 6.6 & 10 & 6.6 & 110 & 5.8 & 32 & 8.0 \\
\hline $0.5 \% \mathrm{KCl}$ & 13 & 6.9 & 13 & 7.0 & 85 & 5.5 & 30 & 6.2 \\
\hline $1.0 \% \mathrm{KCl}$ & 11 & 6.5 & 13 & 6.6 & 75 & 6.2 & 39 & 6.0 \\
\hline $\begin{array}{l}0.025 \% \mathrm{MgSO}_{4} 7 \mathrm{H}_{2} \mathrm{O} \\
1 \% \mathrm{NaCl}\end{array}$ & 15 & 6.5 & 13 & 6.6 & 34 & 6.2 & 34 & 6.2 \\
\hline $\begin{array}{l}0.0001 \% \mathrm{FeSO}_{4} 7 \mathrm{H}_{-} \mathrm{O} \\
1 \% \mathrm{NaCl}\end{array}$ & 12 & 6.8 & 11 & 6.6 & 50 & 5.8 & 43 & 6.2 \\
\hline $\begin{array}{l}0.001 \% \mathrm{FeSO} 47 \mathrm{H}_{2} \mathrm{O} \text {, } \\
1 \% \mathrm{NaCl}\end{array}$ & 10 & 6.8 & 12 & 6.8 & 63 & 6.0 & 44 & 6.0 \\
\hline $\begin{array}{l}0.01 \% \mathrm{FeSO}_{4} 7 \mathrm{H}_{2} \mathrm{O} \\
1 \% \mathrm{NaCl}\end{array}$ & 10 & 7.0 & - & 6.8 & 65 & 6.2 & 39 & 6.0 \\
\hline $0.1 \% \mathrm{FeSO}_{4} 7 \mathrm{H}_{2} \mathrm{O}, 1 \% \mathrm{NaCl}$ & 12 & 6.4 & 9 & 6.5 & 54 & 6.0 & 39 & 5.8 \\
\hline $0.05 \% \mathrm{~K}_{2} \mathrm{HPO}_{4}, 0.5 \% \mathrm{NaCl}$ & - & - & - & $\ldots$ & 84 & 6.2 & 48 & 6.2 \\
\hline
\end{tabular}

Basal medium: $3 \%$ Corn steep liquor and $3 \%$ glycerol at $\mathrm{pH} 7.0$.

nitrate, ammonium sulfate and sodium nitrate the better results have not been obtained.

Among the carbon sources, glycerol seems to be most adequate for the production of the antibiotic substance, as shown in Table 2. The effect of sodium chloride, potassium chloride, potassium phósphate, magnesium sulfate and ferrous sulfate on the production of the antibiotic substance was tested and the results are shown in Table 3. The antibiotic substance seems to be more produced with $1 \%$ sodium chloride than with $0.5 \%$. Sodlum chloride can be substituted with potassium chloride and there is almost none of the influence of potassium phosphate and magnesium sulfate. Ferrous sulphate seems. rather to inhibit the production.

\section{Extraction}

During the fermentation the broth and mycelium become yellow and on the wall of flasks yellow coloured substance appears. Since the culture liquid and mycelium contain the antibiotic substance, so the broth with mycelium is extracted with ethylacetate (half volume of the broth). The antibiotic substance goes into the ethylacetate layer which becomes yellow. The ethylacetate solution is concentrated to its about fifth volume by vacuum distillation at $50^{\circ} \mathrm{C}$. The concentrated ethylacetate solution is dehydrated with anhydrous sodium sulfate, and passed through aluminium oxide column. Then the column is washed with ethylacetate. The first passing solution is faint greenish yellow and does not show any antibiotic activity. On the column a beautiful yellow ring is observed and this ring decends during washing with ethylacetate. When this ring reached the bottom of the column, the passing solution becomes yellow and this part of 
the passing solution contains almost all of the antibiotic activity. A red ring appears above the yellow ring, but in this part almost none of the activity is found.

The yellow ethylacetate solution is concentrated in vacum at $50^{\circ} \mathrm{C}$, until yellow crystals appear. Then the concentrate is placed in the cold for about 24 hours. The antibiotic substance is obtained in yellow thready crystals. It is again recrystallized with ethylacetate.

\section{Characters of the antibiotic substance.}

It is insoluble in distilled water, and slightly soluble in ethylacetate, butylacetate, acetone, benzol, ether, and alochol. It is stable in neutral and acid solution. Its decomposing point lies at $254^{\circ} \mathrm{C}$, if it is tested in the sulfuric bath. It sublimates near at $200^{\circ} \mathrm{C}$ under vacuum, and after sublimation it does not decrease the antibiotic activity. Its chemical nature in detail will be published in the next report.

It inhibits both gram positive and negative bacteria, as its bacterio-static effects tested by agar streak method are shown in Table 4. The antibiotic substance was dissolved in acetone at first, and diluted with the nutrient agar. Then the broth cultures of various bacteria were streaked, and after 24 hours at $37^{\circ} \mathrm{C}$ the bacteriostatic effect of the antibiotic substance was measured. Since the antibiotic substance was insoluble in distilled water, so it was suspednded in the water containing gum accacia and then injected subcutaneously into mice. In the case of $5 \mathrm{mg}$ injection mice survived, but in the case of $10 \mathrm{mg}$ injection mice died in 24 hours.

Table 4. Bacteriostatic effect of aureothricin tested by agar streak method.

\begin{tabular}{l|c}
\hline \multicolumn{1}{c|}{ Species of bacteria } & $\begin{array}{c}\text { Maximum dilution of aureomycin } \\
\text { for complete inhibition } \times 10,000\end{array}$ \\
\hline Staphylococcus aureus (209-p) & 40 \\
S. hemolyticus & 10 \\
Pneumococcus (Type I) & 20 \\
Pneumococcus (Type II) & 40 \\
C. diphtheriae & 5 \\
B. anthracis & 80 \\
H. influenzae & 40 \\
H. pertussis & 40 \\
E. typhi & 40 \\
B. paratyphi A & 40 \\
S. dysenteriae & 40 \\
S. paradysenteriae (Komagame A) & 20 \\
E. coli & 40 \\
P. aeruginosa & 5 \\
B. melitensis & 20 \\
M. tuberculosis avis & 10 \\
M. phlei & 20 \\
\hline
\end{tabular}

DiscUSSION

The yellow crystalline antibiotic substance here described inhibits widely gram positive 
and negative bacteria at the dilution of about $1: 100,000-800,000$, and this effect is not due to impurities, because it yet maintained the antibiotic activity even after the sublimation.

Hitherto many kinds of antibiotic substances have been obtained from streptomyces, but there are only two, which are yellow coloured, that is, aureomycin and xanthom ycin. Aureomycin inhibits widely gram positive and negative bacteria at the dilution of about $1: 100,000-1,000,000$, so in the point of the antibacterial spectrum it seems to be resembling fairly to the substance here described. But the latter is insoluble in water, and we found that it was more toxic than chloromycetin. The solubilities and the toxicity seem to suggest that the substance here obtained is different from aureomycin. If it is compared with xanthomycin, xanthomycin is more toxic than the former and soluble in water, so they seem to be different each other.

In the literature we can not find the species completely identical with the strain No. 26A. No. $26 \mathrm{~A}$ seems to be a new species. So we should like to call the antibiotic substance of $26 \mathrm{~A}$ strain aureothricin, because it is yellow coloured. It inhibits gram positive and negative bacteria, but it seems not to have a great therapeutic meaning, for chloromycetin which is more non-toxic and shows the almost same bacteriostatic activity has been already found.

\section{SUMMARY}

(1) From a strain resembling to A. farcinicus the antibiotic substance of the yellow thready crystals was obtained. It inhibits the growth of gram positive and negative bacteria at the dilution of about $1: 100,000-800,000$. It is more toxic than chloromycetin. (2) It is insoluble in water, and soluble in organic solvents. It decomposes at $254^{\circ} \mathrm{C}$, and it sublimates near at $200^{\circ} \mathrm{C}$.

\section{REFERENCES}

1) Umezawa, H., Hayano, S., and Ogata, Y.:' Classification of antibiotic strains of streptomyces and their antibiotic substances on the basis of their antibacterial spectra. Jap. Med. J. 1, 504, 1948.

2) Paine, T. F., Collins, Jr. H. S. and Finland, M.: Bacteriologic Studies on Aureomycin. J. Bact. 56, No. 4, p. 489, 1948.

3) Thorne, C. B., and Peterson. W. H.: Xanthomycin A and B. New Antibiotics produced by a species of Streptomyces. J. Biol. Chem., 176, 413-428, 1948. 